\title{
The morbidity and mortality of COVID-19 are correlated with the lle105Val glutathione S-transferase P1 polymorphism
}

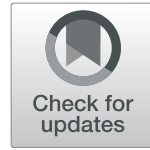

\author{
Mostafa Saadat(10
}

\begin{abstract}
Background: Oxidative stress is an important issue in coronavirus disease 2019 (COVID-19). Considering that glutathione S-transferase P1 (GSTP1) is involved in cellular detoxification, it may play an important role in susceptibility to infection with SARS-CoV-2 and/or its outcome. In the present study, the association between the lle105Val GSTP1 polymorphism (rs1695) and susceptibility to SARS-CoV-2 infection, as well as its outcome was investigated. Data on the prevalence (per $10^{6}$ people), case-fatality (per 100 infected cases), and mortality (per $10^{6}$ people) of COVID-19 and various potential confounders (the life expectancy at birth, density of medical doctors, density of nursing and midwifery personnel, and the gross national income per capita) were used. The latest data available for 45 countries were used for the study.

Results: In multivariate linear regression analyses, the Val105 allelic frequency showed positive association with the logprevalence (partial $r=0.308, p=0.042$ ) and log-mortality of COVID-19 (partial $r=0.316, p=0.037$ ). The log-fatality did not show association with the allelic frequency. In the next step, only countries with the gross national income per capita more than $\$ 15,000$ were included in the analysis. In the selected countries, the frequency of Val105 was positively associated with the log-prevalence (partial $r=0.456, p=0.009$ ) and log-mortality of COVID-19 (partial $r=0.544, p=0.001$ ).
\end{abstract}

Conclusions: The present findings indicate that countries with higher Val105 allelic frequency of the rs 1695 polymorphism showed higher prevalence and mortality of COVID-19.

Keywords: Ecologic study, Epidemiologic measures, Pandemic

\section{Background}

Numerous gene families, including glutathione $S$-transferases (GSTs) superfamily, are involved in cellular detoxification process and neutralizing oxidative stress. The GSTP1 (MIM: 134660, belong to class pi) has many genetic variations in human. A missense variant $\mathrm{A} / \mathrm{G}$ (rs1695) in exon 5 of the GSTP1 result in amino acid substitution Ile105Val. The stability of the Val105 form is less than the other form [1]. This alteration decreased the GSTP1 enzyme activity [2-4].

The GSTP1 is expressed in all tissues and cells, including lung epithelial cells and lung-resident macrophages [5-7]. In occupationally di-isocyanate-induced asthma,

Correspondence: saadat@shirazu.ac.i

Department of Biology, College of Sciences, Shiraz University, Shiraz 71467-13565, Iran the Val105 allele is positively associated with the bronchial hyperreactivity [8]. Exposure to high "diesel exhaust particle" increased the risk of wheezing phenotypes only among the carriers of the Val105 allele (Ile/Val and Val/ Val genotypes) [9]. Children with the Val/Val genotype had slower lung function growth than the other genotypes [10]. Downregulation of the GSTP1 mRNA level and lower total GST activity were reported in a mouse model of asthma following allergen challenge [11]. Taken together, it is concluded that the GSTP1 has a central role in lung function.

Coronavirus disease 2019 (COVID-19) is a contagious disease; therefore, its prevalence (per $10^{6}$ people), casefatality (per 100 infected cases), and mortality (per $10^{6}$ people) may be affected by various social factors, such as the life expectancy at birth, country income, etc. Very

\section{Springer Open}

(c) The Author(s). 2020 Open Access This article is licensed under a Creative Commons Attribution 4.0 International License, which permits use, sharing, adaptation, distribution and reproduction in any medium or format, as long as you give appropriate credit to the original author(s) and the source, provide a link to the Creative Commons licence, and indicate if changes were made. The images or other third party material in this article are included in the article's Creative Commons licence, unless indicated otherwise in a credit line to the material. If material is not included in the article's Creative Commons licence and your intended use is not permitted by statutory regulation or exceeds the permitted use, you will need to obtain permission directly from the copyright holder. To view a copy of this licence, visit http://creativecommons.org/licenses/by/4.0/. 
Table 1 Correlation between log-transformed of epidemiologic parameters and selected risk factors

\begin{tabular}{|c|c|c|c|c|c|c|}
\hline \multirow[t]{2}{*}{ Variables } & \multicolumn{2}{|c|}{$\underline{\text { Log-Prevalence }}$} & \multicolumn{2}{|c|}{ Log-Mortality } & \multicolumn{2}{|c|}{ Log-Fatality } \\
\hline & $r$ & $P$ & $r$ & $P$ & $r$ & $p$ \\
\hline Log-GNI per capita & 0.406 & 0.006 & 0.349 & 0.019 & 0.065 & 0.673 \\
\hline Log-number of COVID-19 diagnostic tests performed (per $10^{6}$ people) & 0.443 & 0.002 & 0.241 & 0.111 & -0.159 & 0.297 \\
\hline Life expectancy at birth (years) & 0.091 & 0.551 & 0.187 & 0.220 & 0.193 & 0.204 \\
\hline Density of medical doctors (per $10^{4}$ people) & 0.384 & 0.009 & 0.393 & 0.008 & 0.162 & 0.287 \\
\hline Density of nursing and midwifery personnel (per $10^{4}$ people) & 0.288 & 0.055 & 0.251 & 0.096 & 0.048 & 0.752 \\
\hline
\end{tabular}

*Degree of freedom (df) for all correlations is 43

recently some investigators suggested that some genetic polymorphisms might be involved in susceptibility to genetic polymorphisms or outcome of the disease [12-16].

Oxidative stress is an important issue in COVID-19 [17-19]. Considering that GSTP1 is involved in cellular detoxification and it has important role in lung function, it is suggested that GSTP1 plays an important role in susceptibility to SARS-CoV-2 infection and/or its outcome. Very recently, association between some genetic polymorphisms and morbidity/mortality of COVID-19 were reported [12-16]. A study showed that the COVID-19 mortality and case-fatality are associated with the GSTT1 polymorphism [12]. There are no data on the association between COVID-19 epidemiologic parameters and the rs1695. These facts sufficiently provide us with a theoretical hypothesis to carry out the present study.

\section{Methods}

In this study, the life expectancy at birth (LE), density of medical doctors, density of nursing and midwifery personnel, and the gross national income (GNI) per capita (PPP international \$) as the indices for economic situation and health services in different countries were considered as the potential risk factors for susceptibility to COVID-19 or the disease outcome. The latest data available for countries were achieved from the World Health Organization website www.who.int/countries/en/. The latest data for GNI per capita for countries were obtained from the World Bank data (https://data.worldbank.org/indicator/NY.GNP.PCAP.PP.CD).

The number of COVID-19 diagnostic tests performed per one million population in each country was also used as another risk variable. Data for the prevalence, fatality, mortality, and level of performed diagnostic test of COVID-19 on July 7, 2020, were achieved from the website www.worldo meters. info/coronavirus/countries. The Val105 allelic frequency in different countries was obtained from previous reports (Table S1 in supplement file). Data from 45 countries were included in the analysis. Data from Argentina, Australia, Brazil, Bulgaria, Canada, China, Colombia, Czech, Denmark, Egypt, Finland, France, Germany, Hungary, Iceland, India, Iran, Iraq, Italy, Jamaica, Japan, Jordan, Kazakhstan, Lebanon, Mexico, Moldova, Morocco, Netherland, Norway, Poland, Portugal, Romania, Russia, Saudi Arabia, Serbia, Singapore, Slovenia, South Africa, South Korea, Spain, Sweden, Thailand, Turkey, the UK, and the USA were included in the analysis.

Variables were checked for their normality by onesample Kolmogorov-Smirnov test. Non-normally

Table 2 Multivariable linear regression analysis for associations of log-mortality and log-prevalence of COVID-19 with the frequency of the Val105 allele in the various countries around the world

\begin{tabular}{|c|c|c|c|c|c|c|}
\hline \multirow[t]{2}{*}{ Variables } & \multicolumn{2}{|c|}{ Unstandardized coefficients } & \multirow[t]{2}{*}{ Standardized coefficients beta } & \multirow[t]{2}{*}{ Partial correlations } & \multirow[t]{2}{*}{$t$} & \multirow[t]{2}{*}{$P$} \\
\hline & $B$ & Std. Error & & & & \\
\hline \multicolumn{7}{|c|}{ Log-prevalence as dependent variable } \\
\hline Constant & -1.067 & 1.231 & - & - & -0.867 & 0.391 \\
\hline Log-GNI per capita & 0.815 & 0.262 & 0.407 & 0.424 & 3.034 & 0.004 \\
\hline Val105 allelic frequency & 0.020 & 0.009 & 0.281 & 0.308 & 2.094 & 0.042 \\
\hline \multicolumn{7}{|c|}{ Log-mortality as dependent variable } \\
\hline Constant & -3.2348 & 1.648 & - & - & -1.971 & 0.055 \\
\hline Log-GNI per capita & 0.918 & 0.359 & 0.350 & 0.367 & 2.553 & 0.014 \\
\hline Val105 allelic frequency & 0.027 & 0.013 & 0.296 & 0.316 & 2.156 & 0.037 \\
\hline
\end{tabular}

The first model was significant with $F=6.76 ; \mathrm{df}=2,42 ; P=0.003$; adjusted $R^{2}=0.207$. The second model was significant with $F=5.55 ; \mathrm{df}=2,42 ; P=0.007 ;$ adjusted $R^{2}=0.171$ 
Table 3 Correlation between log-transformed of epidemiologic parameters and possible confounders in selected countries with GNI-per capita more than $\$ 15,000$

\begin{tabular}{|c|c|c|c|c|c|c|}
\hline \multirow[t]{2}{*}{ Variables } & \multicolumn{2}{|c|}{ Log-Prevalence } & \multicolumn{2}{|c|}{ Log-Mortality } & \multicolumn{2}{|c|}{ Log-Fatality } \\
\hline & $r$ & $P$ & $r$ & $P$ & $r$ & $p$ \\
\hline Log-GNI per capita & 0.527 & 0.001 & 0.353 & 0.041 & -0.084 & 0.637 \\
\hline Log-number of COVID-19 diagnostic tests performed (per $10^{6}$ people) & 0.541 & 0.001 & 0.261 & 0.136 & -0.230 & 0.190 \\
\hline Life expectancy at birth (years) & 0.141 & 0.426 & 0.240 & 0.171 & 0.191 & 0.278 \\
\hline Density of medical doctors (per $10^{4}$ people) & 0.469 & 0.005 & 0.461 & 0.006 & 0.139 & 0.434 \\
\hline Density of nursing and midwifery personnel (per $10^{4}$ people) & 0.243 & 0.166 & 0.172 & 0.332 & -0.030 & 0.866 \\
\hline
\end{tabular}

Degree of freedom ( $d f$ ) for all correlations is 32

distributed variables (prevalence, mortality, case-fatality rates, and number diagnostic test performed per $10^{6}$ people) were log-transformed.

Variables with $p \leq 0.1$ in the univariable analysis were introduced into the multivariable models. Only two different models were fitted for combination of the epidemiologic parameters with the rs 1695 polymorphism. The log-transformed variables were considered as outcome variables, and the allelic frequency and the risk factors were introduced into the model as explanatory variables. A backward removal method was used for each model construction. Analyses were performed using the SPSS statistical soft-ware (Chicago, IL, USA, version 24). A $p$ $<0.05$ was considered statistically significant difference

\section{Results}

In univariate analysis, the frequency of the Val105 allele showed no significant correlations with the logprevalence $(r=0.331, \mathrm{df}=44, p=0.025)$, log-mortality $(r=0.363, \mathrm{df}=44, p=0.013)$, and log-fatality $(r=0.175$, $\mathrm{df}=44, p=0.244)$ of the COVID-19.
Table 1 shows the association between potential risk factors and the log-transformed of prevalence, mortality, and case-fatality of COVID-19. Variables with $p \leq 0.1$ in the univariable analysis were used in multivariable linear regression analyses (Table 1 ).

Two different models were fitted for combination of prevalence and mortality with the rs 1695 polymorphism. The log-prevalence and log-mortality were considered as outcome variables, and the Val105 allelic frequency and the risk factors were introduced into the model as explanatory variables.

Results of multivariate analysis are summarized in Table 2. Based on multivariate analyses, the frequency of Val105 was positively associated with the log-mortality (partial $r=0.316, p=0.037$ ) and log-prevalence of COVID-19 (partial $r=0.308, p=0.042$ ).

In next step, only countries with the gross national income (GNI) per capita (PPP international \$) more than $\$ 15,000$ were included in the analysis. Table 3 summarizes the associations between the risk factors and the log-transformed of epidemiologic parameters of COVID19 in the selected countries. The results of multivariate

Table 4 Multivariable linear regression analysis for associations of log-mortality and log-prevalence of COVID-19 with the frequency of the Val105 allele in the various countries around the world in selected countries with GNI-per capita more than $\$ 15,000$

\begin{tabular}{|c|c|c|c|c|c|c|}
\hline \multirow[t]{2}{*}{ Variables } & \multicolumn{2}{|c|}{ Unstandardized coefficients } & \multirow[t]{2}{*}{ Standardized coefficients beta } & \multirow[t]{2}{*}{ Partial correlations } & \multirow[t]{2}{*}{$t$} & \multirow[t]{2}{*}{$P$} \\
\hline & $B$ & Std. Error & & & & \\
\hline \multicolumn{7}{|c|}{ Log-prevalence as dependent variable } \\
\hline Constant & -4.790 & 1.717 & - & - & -2.789 & 0.009 \\
\hline Log-test & 0.429 & 0.194 & 0.319 & 0.374 & 2.209 & 0.035 \\
\hline Log-GNI per capita & 1.118 & 0.417 & 0.384 & 0.440 & 2.681 & 0.012 \\
\hline Val105 allelic frequency & 0.028 & 0.010 & 0.360 & 0.456 & 2.806 & 0.009 \\
\hline \multicolumn{7}{|c|}{ Log-mortality as dependent variable } \\
\hline Constant & -5.979 & 2.463 & - & - & -2.427 & 0.021 \\
\hline Log-GNI per capita & 1.344 & 0.530 & 0.358 & 0.415 & 2.537 & 0.016 \\
\hline Val105 allelic frequency & 0.051 & 0.014 & 0.509 & 0.544 & 3.606 & 0.001 \\
\hline
\end{tabular}

The first model was significant with $F=10.726 ; \mathrm{df}=3,30 ; P<0.001$; adjusted $R^{2}=0.469$. The second model was significant with $F=9.63 ; \mathrm{df}=2,31 ; P<0.001$; adjusted $R^{2}=0.344$ 
analysis are summarized in Table 4 . In the selected countries, the frequency of Val105 was positively associated with the log-prevalence (partial $r=0.456, p=$ 0.009 ) and log-mortality of COVID-19 (partial $r=0.544$, $p=0.001)$.

\section{Discussion}

The main findings of the present study are that the frequency of Val105 was positively associated with the logprevalence and log-mortality of COVID-19. It means that countries with higher Val105 allelic frequency showed higher prevalence of COVID-19 and mortality due to COVID-19. The present findings may explain, at least in part, some differences in COVID-19 mortality between East Asian and European populations by the Val105 allelic frequency.

Numerous facts are indicated that GSTP1 plays an important role in lung function [5, 8-11, 20]. GSTP1 has pleiotropic properties; it binds directly to c-Jun Nterminal kinases and acts as a negative regulator. It also has a negative regulatory role in regulating tumor necrosis factor-alpha (TNF $\alpha$ )-induced MAPK signaling. These functions are independent from its enzyme activity [21].

It is widely acknowledged that the mortality due to severe respiratory problems in patients infected by SARSCoV-2 is high [22]. On the other hand, COVID-19 is associated with oxidative stress $[17,18]$. It is suggested that COVID-19 mortality might be associated with oxidative stress and/or SARS-CoV-2-activated cytokine storm syndrome. Both of these phenomena might be interpreted with the pleiotropy properties of GSTP1.

It is worth mentioning that the Val105 form compared to the other form has lower detoxification activity; therefore, COVID-19 patients, who are carriers of Val105, often experience severe oxidative stress compared to the Ile/Ile genotype. This may lead to severity of the disease and subsequently death due to COVID-19 in the carriers of Val105.

A literature review indicated that COVID-19 has affected more males than females, and also male gender significantly increases the case fatality $[23,24]$. This difference, at least in part, may be explained by the sexual dimorphisms of GSTP1 enzyme activity. The enzyme activity is higher in females than males [25]. Several observational and experimental studies should be carried out to approve the present findings and the abovementioned hypotheses.

\section{Conclusions}

The present findings indicate that countries with Val105 higher allelic frequency of the rs1695 polymorphism showed higher prevalence and mortality of COVID-19.

\section{Supplementary information}

Supplementary information accompanies this paper at https://doi.org/10. 1186/s43042-020-00094-0.

Additional file 1: Table S1. Prevalence, mortality and case-fatality of COVID-19 in 46 countries, the genotypic frequency of the GSTP1 lle105Val polymorphism and other variables used in the study

\section{Abbreviations}

COVID-19: Coronavirus disease 2019; df: Degree of freedom; GSTP1: Glutathione S-transferase P1; GNI: Gross national income

\section{Acknowledgements}

None

Author's contributions

Study design, data collection, data analysis, and writing the article are done by MS. The author read and approved the final manuscript.

\section{Funding}

None

Availability of data and materials

All data generated or analyzed during this study are included in this published article and its supplementary information file.

\section{Ethics approval and consent to participate}

None

Consent for publication

None

Competing interests

None

Received: 13 July 2020 Accepted: 1 September 2020

Published online: 01 October 2020

References

1. Johansson AS, Stenberg G, Widersten M, Mannervik B (1998) Structureactivity relationships and thermal stability of human glutathione transferase P1-1 governed by the H-site residue 105. J Mol Biol 278:687-698

2. Ali-Osman F, Akande O, Antoun G, Mao JX, Buolamwini J (1997) Molecular cloning, character-rization, and expression in Escherichia coli of full-length cDNAs of three human glutathione S-transferase Pi gene variants. Evidence for differential catalytic activity of the encoded proteins. J Biol Chem 272: 10004-10012

3. Sundberg K, Johansson AS, Stenberg G et al (1998) Differences in the catalytic efficiencies of allelic variants of glutathione transferase P1-1 towards carcinogenic diol epoxides of polycyclic aromatic hydrocarbons. Carcinogenesis 19:433-436

4. Zimniak P, Nanduri B, Pikula S et al (1994) Naturally occurring human glutathione S-transferase GSTP1-1 isoforms with isoleucine and valine in position 104 differ in enzymic properties. Eur J Biochem 224:893-899

5. Terrier P, Townsend AJ, Coindre JM et al (1990) An immunohistochemical study of pi class glutathione S-transferase expression in normal human tissue. Am J Pathol 137:845-853

6. Moscow JA, Fairchild CR, Madden MJ et al (1989) Expression of anionic glutathione-S-transferase and P-glycoprotein genes in human tissues and tumors. Cancer Res 49:1422-1428

7. Saint-Georges F, Abbas I, Billet S et al (2008) Gene expression induction of volatile organic compound and/or polycyclic aromatic hydrocarbonmetabolizing enzymes in isolated human alveolar macrophages in response to airborne particulate matter (PM2.5). Toxicology 244:220-230

8. Leppilahti J, Majuri ML, Sorsa T et al (2019) Associations between glutathione-S-transferase genotypes and bronchial hyperreactivity patients with di-isocyanate induced asthma. A follow-up study. Front Med (Lausanne) 6:220 
9. Schroer KT, Biagini Myers JM, Ryan PH et al (2009) Associations between multiple environmental exposures and glutathione S-transferase P1 on persistent wheezing in a birth cohort. J Pediatr 154:401-408.e1

10. Gilliland FD, Gauderman WJ, Vora H, Rappaport E, Dubeau L (2002) Effects of glutathione S-transferase $\mathrm{M} 1, \mathrm{~T} 1$, and $\mathrm{P} 1$ on childhood lung function growth. Am J Respir Crit Care Med 166:710-716

11. Schroer KT, Gibson AM, Sivaprasad U et al (2011) Downregulation of glutathione S-transferase pi in asthma contributes to enhanced oxidative stress. J Allergy Clin Immunol 128:539-548

12. Saadat M (2020) An evidence for correlation between the glutathione Stransferase T1 (GSTT1) polymorphism and outcome of COVID-19. Clin Chim Acta 508:213-216

13. Saadat M (2020) No significant correlation between ACE Ins/Del genetic polymorphism and COVID-19 infection. Clin Chem Lab Med 58:1127-1128

14. Ansari-Lari M, Saadat M (2020) The morbidity and mortality of COVID-19 are associated with $\mathrm{ABO}$ and Rh blood groups. Eur J Prev Cardiol 7: 2047487320939216. https://doi.org/10.1177/2047487320939216

15. Kuo CL, Pilling LC, Atkins JL, et al. APOE e4 genotype predicts severe COVID-19 in the UK Biobank community cohort. J Gerontol A Biol Sci Med Sci 2020; glaa131, Doi: https://doi.org/10.1093/gerona/glaa131

16. Delanghe JR, De Buyzere ML, Speeckaert MM (2020) C3 and ACE1 polymorphisms are more important confounders in the spread and outcome of COVID-19 in comparison with ABO polymorphism. Eur J Prev Cardiol 27:1331-1332

17. Khomich O, Kochetkov S, Bartosch B, Ivanov AV (2018) Redox biology of respiratory viral infections. Viruses 10:392

18. Henry BM, Vikse J, Benoit S et al (2020) Hyperinflammation and derangement of renin-angiotensin-aldosterone system in COVID-19: A novel hypothesis for clinically suspected hypercoagulopathy and micro-vascular immunothrombosis. Clin Chim Acta 507:167-173

19. Shneider A, Kudriavtsev A, Vakhrusheva A (2020) Can melatonin reduce the severity of COVID-19 pandemic? Int Rev Immunol 29:1-10

20. Piacentini S, Polimanti R, Simonelli I et al (2013) Glutathione S-transferase polymorphisms, asthma susceptibility and confounding variables: a metaanalysis. Mol Biol Rep 40:3299-3313

21. Zhang J, Grek C, Ye ZW et al (2014) Pleiotropic functions of glutathione Stransferase P. Adv Cancer Res 122:143-175

22. de Lusignan S, Dorward J, Correa A, et al. Risk factors for SARS-CoV-2 among patients in the Oxford Royal College of general practitioners research and surveillance center primary care network: a cross-sectional study. Lancet Infect Dis 2020;\$1473-3099(20)30371-6.

23. Kowalewski M, Fina D, Słomka A et al (2020) COVID-19 and ECMO: the interplay between coagulation and inflammation-a narrative review. Crit Care 24:205

24. Nikpouraghdam M, Jalali Farahani A, Alishiri G et al (2020) Epidemiological characteristics of coronavirus disease 2019 (COVID 19) patients in IRAN: a single center study. J Clin Virol 127:104378

25. Wang L, Ahn YJ, Asmis R (2020) Sexual dimorphism in glutathione metabolism and glutathione-dependent responses. Redox Biol 31:10410

\section{Publisher's Note}

Springer Nature remains neutral with regard to jurisdictional claims in published maps and institutional affiliations.

\section{Submit your manuscript to a SpringerOpen ${ }^{\circ}$ journal and benefit from:}

- Convenient online submission

- Rigorous peer review

- Open access: articles freely available online

- High visibility within the field

- Retaining the copyright to your article

Submit your next manuscript at $\boldsymbol{\nabla}$ springeropen.com 